\title{
PERANCANGAN VALIDASI PENGAJUAN E-KWITANSI ZISWAF PADA LEMBAGA AMIL ZAKAT MENGGUNAKAN KONSEP FINITE STATE AUTOMATA
}

\author{
Dedi Irawan', Ricko Anugrah Mulya Pratama², Bobby Suryo Prakoso ${ }^{3}$, Sri Rahayu ${ }^{4}$, \\ ${ }^{5}$ Windu Gata
}

\author{
1,2,3,5 Program Studi Ilmu Komputer, Universitas Nusa Mandiri, Jakarta, Indonesia \\ ${ }^{4}$ Program Studi Informatika, Universitas Nusa Mandiri, Jakarta, Indonesia \\ ${ }^{1} 14207097 @$ nusamandiri.ac.id, ${ }^{2} 14207093 @$ nusamandiri.ac.id, \\ 33bobby.byp@nusamandiri.ac.id, ${ }^{4}$ srirahayu.rry@nusamandiri.ac.id, ${ }^{5}$ windu@ @nusamandiri.ac.id
}

\begin{abstract}
ABSTRAK
Lembaga Amil Zakat (LAZ) dalam mengerjakan tugas dan pokok fungsinya sebagai penyalur zakat infaq shodaqoh dan wakaf (ZISWAF), juga memberikan kepercayaan kepada para donatur yang berdonasi yang membutuhkan sebuah bukti kwitansi. Dalam Pengajuan kwitansi para petugas penerima zakat masih mendata donatur secara manual dengan menulis di kertas kwitansi, sehingga dalam waktu validasi tidak efisien dan juga dilain waktu bukti kwitansi bisa saja hilang. Penelitian ini bertujuan untuk membuat rancangan sebuah sistem yang dapat mengolah data ziswaf untuk pengajuan elektronik kwitansi. Sehingga dapat mengurangi penggunaan waktu yang lama, membantu mengurangi terjadinya kesalahan input data, memudahkan para petugas untuk memvalidasi data dari donasi yang telah di terima oleh petugas LAZ sebelum data tersebut disimpan ke dalam database menggunakan Finite State Automata (FSA) agar data yang tersimpan sesuai dengan format yang ditentukan. Dengan adanya penelitian ini diharapkan membantu para petugas penerima ZISWAF dalam mengelola data donatur yang lebih professional, mengurangi kesalahan dalam pencatatan kwitansi dan bisa menghasilkan e-kwitansi yang sesuai dengan data donatur yang berdonasi.
\end{abstract}

Kata Kunci- Finite State Automata, Validasi, ZISWAF

\begin{abstract}
The Amil Zakat Institution (LAZ) in carrying out its duties and main functions as a distributor of zakat, infaq shodaqoh and waqf (ZISWAF), besides that LAZ also gives trust to donors who donate who need a proof of receipt. In submitting receipts, zakat recipient officers still record donors manually by writing on receipt paper, so that during validation it is not efficient and also at other times proof of receipts may be lost. This study aims to design a system that can process ziswaf data for filing Electronic Receipts. Thus reducing the use of a long time, helping to reduce the occurrence of data input errors, making it easier for officers to validate data from donations that have been received by LAZ officers before the data is stored in the database using Finite State Automata (FSA) so that the data stored is in accordance with the format which is determined. With this research, it is expected to help ZISWAF receiving officers in managing donor data more professionally, reducing errors in recording receipts and being able to produce e-receipts that are in accordance with the data of donors who donate.
\end{abstract}

Keywords - Finite State Automata, Validation, ZISWAF 


\section{PENDAHULUAN}

Dalam agama islam bahwasanya harta yang ada dalam diri seseorang masih ada hak orang lain yang harus disalurkan. Sebab itu seseorang yang tidak mengeluarkan hartanya untuk orang lain hartanya bisa jadi tidak berkah. Indonesia merupakan negara yang mayoritas penduduknya memeluk agama islam, dengan banyaknya pemeluk agama islam yang ingin menyalurkan hartanya untuk orang lain, maka diperlukan Lembaga yang terpercaya yang bisa menyalurkan dana terhadap orang lain yang membutuhkan. Menurut Fatwa Majelis Ulama Indonesia Nomor 8 Tahun 2011 tentang Amil Zakat bahwa Amil zakat adalah Seseorang atau sekelompok orang yang diangkat oleh Pemerintah untuk mengelola pelaksanaan ibadah zakat; atau Seseorang atau sekelompok orang yang dibentuk oleh masyarakat dan disahkan oleh Pemerintah untuk mengelola pelaksanaan ibadah zakat[1].

Banyaknya muzaki atau orang yang membayar zakat di Indonesia yang membayarkan zakatnya langsung kepada mustahik atau orang yang menerima zakat tanpa melalui lembaga amil zakat menyebabkan data pembayaran dari muzaki tidak terdata oleh pengelola zakat.Sehingga Profesionalisme lembaga amil zakat dan hasil pengelolaan zakat yang tidak terpublikasi kepada masyarakat luas adalah hal yang membuat kepercayaan masyarakat rendah terhadap lembaga amil zakat. Hal ini menunjukkan kepatuhan masyarakat dalam membayar zakat berbanding lurus dengan peran dari institusi pengelola zakat dalam memberikan pelayanan[2]. Dalam pengelolahan zakat,infaq sedekah, dan wakaf (ZISWAF) yang begitu besar, maka perlu dilakukan manajemen pengelola yang baik, sehingga bisa terwujudnya Lembaga Amil Zakat (LAZ) yang professional.

Pokok masalah dalam pengelolaan ziswaf salah satunya adalah validasi data Donatur untuk proses pembuatan kwitansi yang dilakukan masih secara manual. memungkinkan muzaki harus datang dan bertemu dengan petugas zakat. Padahal dalam musim pandemi yang terjadi saat ini pemberlakuan jaga jarak sangat diperketat lantaran virus covid19 masih belum reda. Sehingga ketika terjadi penumpukan pengambilan kwitansi dan pemberian ziswaf secara manual akan mengakibatkan kerumunan nya masyarakat.Oleh karena itu, LAZ menerapkan pembayaran ZISWAF melalui transfer dengan menggunakan $\mathrm{m}$ banking,

Dalam penelitian ini dibuat rancangan sebuah sistem yang dapat mengolah data ziswaf. Yang dapat membantu LAZ untuk mengurangi penggunaan waktu, membantu mengurangi terjadinya kesalahan input data, memudahkan para petugas untuk memvalidasi data dari donasi yang telah diterima oleh petugas LAZ. serta menyimpannya pada basis data sesuai format yang ditentukan dan akhirnya menghasilkan elektronik kwitansi yang bisa dikirim melalui email Donatur, nomer handphone, kategori donasi, jumlah dana yang akan didonasikan, upload bukti transfer, nomer jurnal virtual account yang telah didonasikan, catatan atau keterangan, Agar data tersebut sesuai dengan kebutuhan penyimpanan ke dalam basis data maka sistem akan melakukan pengecekan input dan melakukan validasi sebelum data disimpan ke dalam basis data agar data yang tersimpan sesuai dengan format yang ditentukan.

\section{TINJAUAN PUSTAKA}

\subsection{Tinjauan Pustaka}

Menurut bahasa kata Zakat berasal dari kata zaka yang berarti berkah, tumbuh, bersih dan baik,Dikatakan berkah dan tumbuh karena diyakini dengan berzakat akan mendapatkan pahala dari Allah SWT. Bagi orang yang menunaikannya dan akan meningkatkan harta yang dimilikinya[3].

Infak/sedekah merupakan donasi sukarela, baik ditentukan maupun tidak ditentukan peruntukannya oleh pemberi infak/sedekah[4].

Sedekah adalah harta atau non harta yang dikeluarkan oleh seseorang atau badan usaha di luar zakat untuk kemaslahatan umum. Dalam istilah syari'at Islam, sedekah sama dengan pengertian infaq, termasuk juga hukum dan ketentuan-ketentuannya. Sisi perbedaan hanya terletak pada bendanya. Artinya, Infaq berkaitan dengan materi dan non materi, baik dalam bentuk pemberian benda atau uang, tenaga atau jasa, menahan diri untuk tidak berbuat kejahatan, mengucapkan takbir, tahmid, tahlil, bahkan yang paling sederhana adalah tersenyum kepada orang lain secara ikhlas [5].

Di Indonesia, pengelolaan zakat diatur dalam Undang - Undang RI Nomor 23 tahun 2011 tentang Pengelolaan Zakat. Dimana dalam undang - undang tersebut terdapat beberapa bab yang menjelaskan tentang lembaga pengelola zakat yang ada di Indonesia yang terdiri dari dua lembaga yaitu: BAZNAS (Badan Amil Zakat Nasional) dan LAZ (Lembaga Amil Zakat). Meskipun dalam peraturan-peraturan tersebut masih banyak kekurangan tetapi undang - undang tersebut mendorong upaya pembentukan lembaga pengelola zakat yang amanah, kuat dan dipercaya oleh masyarakat [6].

FSA merupakan pemodelan matematika dengan masukan berupa sejumlah himpunan terbatas. FSA juga memiliki sekumpulan state yang berhingga, sebuah state awal, dan fungsi transisi untuk berpindah state, serta himpunan bagian dari state untuk menerima hasil menjadi keluaran [7].

Otomata adalah mesin abstrak yang dapat mengenali (recognize), menerima (accept), atau membangkitkan (generate) sebuah kalimat dalam bahasa tertentu[8]. Input pada mesin automata dianggap sebagai bahasa yang harus dikenali oleh mesin. Selanjutnya mesin automata membuat keputusan yang mengindikasikan diterima atau tidaknya input tersebut, sehingga mesin automata dapat dipakai untuk menghasilkan suatu bahasa yang aturannya ditentukan oleh bahasa tersebut[9]. 
Jurnal Ilmiah Ilmu Komputer Vol. 7, No. 2, September 2021

Fakultas Ilmu Komputer

Universitas AL Asyariah Mandar

Berbagai penelitian mengenai Finite State Automata telah banyak diteliti sebelumnya. Jurnal dan penelitian yang membahas kemiripan teori ataupun subjek dijadikan sebagai acuan dalam penelitian ini. Berikut Ada beberapa jurnal yang mirip dengan membahas FSA :

Penelitian pertama yang berjudul "Perancangan Validasi Permohonan Narasumber Pada Sistem Informasi Permohonan Narasumber Menggunakan Finite State Automata" Penelitian ini bertujuan untuk dapat mengurangi penggunaan waktu, membantu memperkecil terjadinya kehilangan surat, serta mengurangi kesalahan dalam pencatatan surat dengan menyimpannya pada basis data sesuai format yang ditentukan[10].

Penelitian kedua yang berjudul "Rancangan Pemilihan Paket Pelaminan Menggunakan Finite State Automata di Kota Batam" pada penelitian ini membahas tentang cara atau diagram yang bisa digunakan untuk membuat keputusan yang simpel dalam pengambilan keputusan terhadap pemilihan paket pelaminan menggunakan FSA[11].

Penelitian ketiga yang berjudul "Desain Vending Machine Rokok Dengan Mengimplementasikan Finite State Automata Terintegrasi Dengan E-KTP" pada penelitian ini membahas tentang desain mesin penjualan rokok otomatis atau vending machine yang terintegrasi dengan database e-KTP untuk mengambil data usia pembeli[12].

Penelitian keempat yang berjudul "Verifying ClientSide Input Validation Functions Using String Analysis" pada penelitian ini membahas tentang penggunaan DFA untuk memverifikasi fungsi validasi input pada sisi klien menggunakan analisis string.[13]

Penelitian kelima yang berjudul "String Analysis for Vulnerability Detection and Repair" penelitian ini membahas tentang Analisis string untuk mendeteksi dan memperbaiki sebuah vulnerability berdasarkan analisis string berbasis automata.[14]

\section{METODE YANG DIUSULKAN}

Tahapan Penelitian yang digunakan dalam penelitian ini dapat dibagi ke dalam 3 (tiga) tahap yaitu: (1) Identifikasi Masalah, (2) Perancangan Finite State Automata, 3) Design Sistem Informasi Permohonan Narasumber

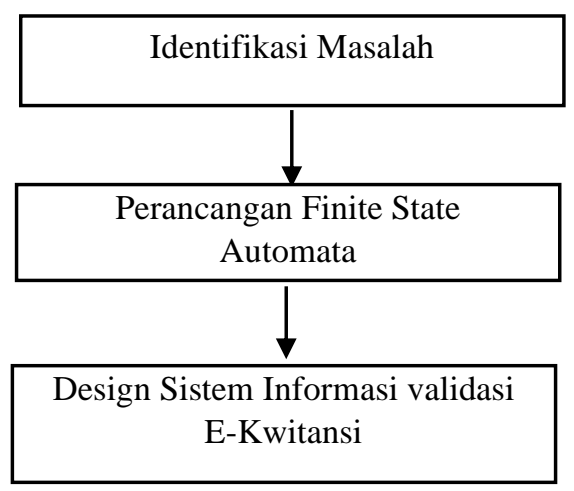

\section{Gambar 1. Tahapan Penelitian}

Pada Gambar 1 menjelaskan tahapan penelitian yang digunakan dalam penelitian ini, sebagai berikut:

1. Tahap Identifikasi Masalah Pada tahap ini dilakukan proses deteksi atas permasalahan-permasalahan yang ada. 2. Tahap Perancangan FSA Pada tahap ini akan dilakukan perancangan FSA menggunakan NFA.

3. Tahap Design Sistem Informasi Permohonan Narasumber Pada tahap ini dilakukan design tampilan antarmuka Sistem Informasi Permohonan Narasumber.

\section{HASIL PENELITIAN (Times New 10 Bold)}

\subsection{Perancangan FSA}

Perancangan FSA menggunakan NFA yang akan dijelaskan pada gambar sebagai berikut :

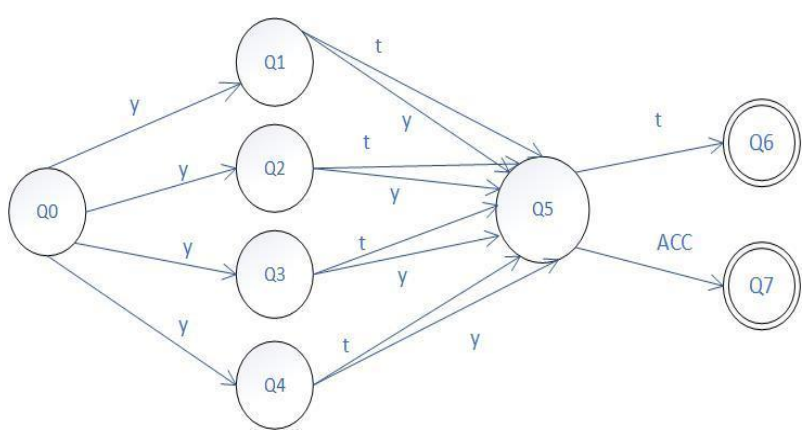

Gambar 2. Diagram state NFA Validasi Donatur

Keterangan :

$\mathrm{Q} 0=$ Status Awal, pengisian form untuk validasi donator

$\mathrm{Q} 1$ = Masukan nomer

Q2 = Masukan nomer jurnal transfer

Q3 = Pilih jenis amalan (infaq,sedekah,zakat)

Q4 = Unggah foto transfer

Q5 = Submit atau data yang dikirim atau tidak

Q6 = Tidak diterima

Q7 = Data diterima

$\mathrm{y}=$ adalah inisial ya untuk state berikutnya

$\mathrm{t}=$ adalah inisial tidak untuk ke state selanjutnya

$\mathrm{ACC}=$ adalah inisial accept

Tabel 1. Relasi Transisi

\begin{tabular}{|c|c|c|c|c|c|c|c|}
\hline $\mathrm{Q}$ & $y$ & $y$ & $y$ & $y$ & $\mathrm{t}$ & $t$ & $\begin{array}{c}\mathrm{AC} \\
\mathrm{C}\end{array}$ \\
\hline Q0 & Q1 & Q2 & Q3 & Q4 & - & - & Q7 \\
\hline Q1 & - & - & - & - & Q5 & Q6 & - \\
\hline
\end{tabular}


Jurnal Ilmiah Ilmu Komputer Vol. 7, No. 2, September 2021

Fakultas Ilmu Komputer

Universitas AL Asyariah Mandar

\begin{tabular}{|c|c|c|c|c|c|c|c|}
\hline Q2 & - & - & - & - & Q5 & Q6 & - \\
\hline Q3 & - & - & - & - & Q5 & Q6 & - \\
\hline Q4 & - & - & Q6 & - & Q5 & Q6 & - \\
\hline Q5 & - & - & - & - & - & Q6 & - \\
\hline Q7 & - & - & - & - & - & - & - \\
\hline
\end{tabular}

Tabel 1 menjelaskan tentang perpindahan state yang ada pada diagram perancangan FSA apabila ada input yang masuk. Sebagai contoh state Q0 mendapatkan input yang lengkap dan benar maka akan berpindah ke state Q1,Q2,Q3,Q5 dan berpindah Kembali ke Q5, namun apabila mendapat input yang tidak lengkap maka akan berpindah ke state Q6. Perpindahan antar state tersebut akan bernilai t jika input yang masuk tidak sesuai. Setelah rancangan NFA selesai dibuat, tahap selanjutnya adalah mengaplikasikan rancangan agar dapat dengan mudah digunakan dan diterapkan pada rancangan sistem agar proses pembuatannya dapat diselesaikan dengan mudah.

\subsection{Desain Sistem Informasi}

Dalam perancangan Sistem Informasi berbasis web, memiliki tampilan utama seperti berikut :

a. Halaman Depan

Halaman utama yang akan tampil jika Petugas

LAZ membuka web validasi donator
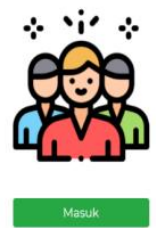

Gambar 3. Halaman Utama web

b. Form pengajuan E-Kwitansi

Digunakan oleh petugas LAZ untuk pengajuan EKwitansi
(P) ISSN 2442-451X

(O) ISSN 2503-3832

LAZ

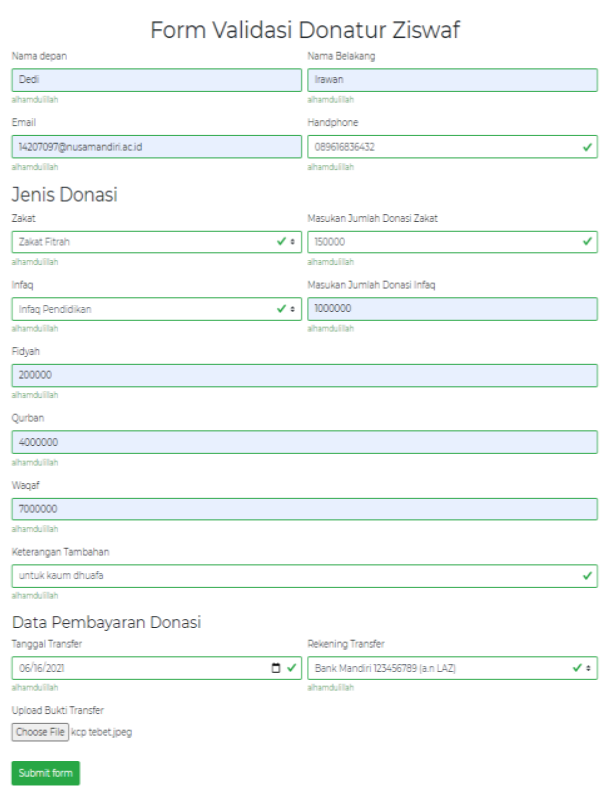

Gambar 4. Form Pengajuan

c. Tampilan validasi ketika form belum sesuai atau tidak di isi, dan akan menampilkan kesalahan seperti berikut

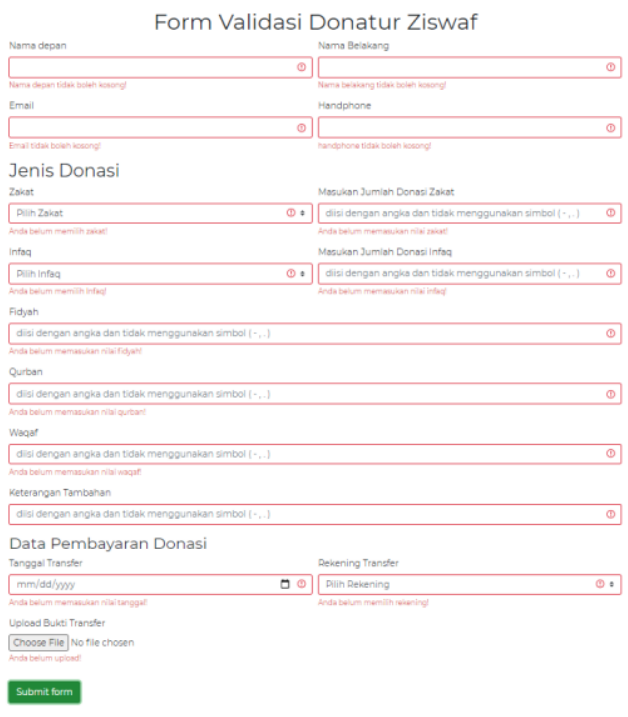

Gambar 5. Form ketika validasi

d. Hasil e-kwitansi yang telah berhasil di submit. 
Jurnal Ilmiah Ilmu Komputer Vol. 7, No. 2, September 2021 Fakultas Ilmu Komputer

Universitas AL Asyariah Mandar

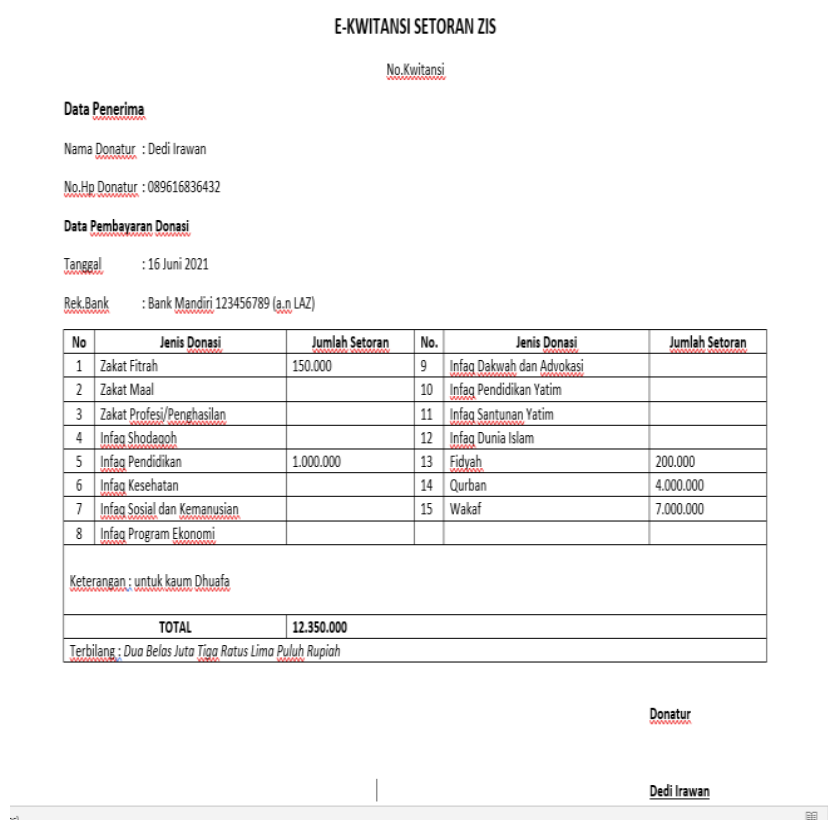

Gambar 6. Hasil e-kwitansi

\section{KESIMPULAN}

Dari hasil penelitian bahwa FSA dapat menjadi logika dasar untuk merancang suatu proses sistem informasi validasi pengajuan e-kwitansi. Dan ini sebagai solusi permasalahan pengajuan kwitansi secara manual.,Syarat untuk menghasilkan e-kwitansi adalah nama, nomer handphone, unggah bukti transfer, dan lainlain itu telah tervalidasi dengan benar sehingga saat form di submit tidak menghasilkan kesalahan. Dengan diterapkan nya penelitian ini diharapkan dapat membantu LAZ untuk mengurangi penggunaan waktu, membantu mengurangi terjadinya kesalahan input data, memudahkan para petugas untuk memvalidasi data dari donasi yang telah di terima oleh petugas LAZ sehingga E-kwitansi adalah bukti bahwa donator telah berdonasi.

\section{UCAPAN TERIMA KASIH}

Terima kasih kepada Allah SWT dan Nabi Muhammad SAW serta seluruh responden yaitu para dosen dan senior tingkat semester atas yang telah memberikan saran dan masukan kepada jurnal ini, sehingga jurnal ini bisa terbit.

\section{Daftar Pustaka}

[1] Majelis Ulama Indonesia, "Fatwa DSN-MUI Nomor 8 Tahun 2011 tentang Amil Zakat," Majelis Ulama Indones., vol. 53, no. 9, pp. 16891699, 2011.

[2] C. Canggih, K. Fikriyah, and A. Yasin, "POTENSI DAN REALISASI DANA ZAKAT INDONESIA," al-Uqud J. Islam. Econ., vol. 1, no. 1, 2017, doi: 10.26740/jie.v1n1.p14-26.

[3] Tatang Ruhiat, "Strategi Pendayagunaan
(P) ISSN 2442-451X

(O) ISSN 2503-3832

STRATEGI PENDAYAGUNAAN ZAKAT PRODUKTIF UNTUK PENGENTASAN KEMISKINAN ( Implementasi Indeks Zakat di LAZISMU )," MALIA (TERAKREDITASI), vol. 11, no. 2, 2020, doi: 10.35891/ml.v11i2.1873.

S. Shahnaz, "Penerapan PSAK No.109 Tentang Pelaporan Keuangan Akuntansi Zakat, Infaq/Sedekah Pada Badan Amil Zakat Provinsi Sulawesi Utara," J. EMBA, vol. 3, no. 4, 2015.

A. Sisweda, S. Sahrani, and R. Susanto, "NILAI PENDIDIKAN ISLAM DALAM TRADISI SEDEKAH BUMI (Studi Kasus di Dusun Melati Desa Olak-Olak Kubu Kecamatan Kubu Kabupaten Kubu Raya Tahun 2019)," J. Res. Thought Islam. Educ., vol. 3, no. 1, 2020, doi: 10.24260/jrtie.v3i1.1707.

[6] A. Yudhira, "ANALISIS EFEKTIVITAS PENYALURAN DANA ZAKAT, INFAK DAN SEDEKAH PADA YAYASAN RUMAH ZAKAT," VALUE, vol. 1, no. 1, 2020, doi: 10.36490/value.v1i1.87.

[7] B. W. Yohanes, T. Robert, and S. Nugroho, "Sistem Penerjemah Bahasa Jawa-Aksara Jawa Berbasis Finite State Automata," J. Nas. Tek. Elektro dan Teknol. Inf., vol. 6, no. 2, 2017, doi: 10.22146/jnteti.v6i2.306.

[8] Widyasari, "Telaah Teoritis Finite State Automata Dengan Pengujian Hasil Pada Mesin Otomata," Sisfotenika, vol. 1, no. 1, pp. 59-67, 2011, [Online]. Available: https://media.neliti.com/media/publications/.

[9] R. Suharsih and F. Atqiya, "Penerapan Konsep Finite State Automata (FSA) pada Aplikasi Simulasi Vending Machine Yoghurt Walagri," Edsence J. Pendidik. Multimed., vol. 1, no. 2, 2019, doi: 10.17509/edsence.v1i2.21778.

[10] F. Said, D. Andriyanto, R. Sari, and W. Gata, "Perancangan Validasi Permohonan Narasumber Pada Sistem Informasi Permohonan Narasumber Menggunakan Finite State Automata," Paradig. J. Komput. dan Inform., vol. 22, no. 2, 2020, doi: 10.31294/p.v22i2.8157.

[11] K. Handoko and A. W. Aranski, "Rancangan Pemilihan Paket Pelaminan Menggunakan Finite State Automata di Kota Batam," SNISTEK, vol. 2, no. 2, 2019.

[12] A. Faisal, G. V. Saragih, and W. Gata, "Desain Vending Machine Rokok Dengan Mengimplementasikan Finite State Automata Terintegrasi Dengan E-KTP," MATICS, vol. 12, no. 1, 2020, doi: 10.18860/mat.v12i1.8693.

[13] M. Alkhalaf, T. Bultan, and J. L. Gallegos, "Verifying client-side input validation functions using string analysis," 2012, doi: 10.1109/ICSE.2012.6227124.

[14] T. Bultan, "String analysis for vulnerability detection and repair," in Lecture Notes in Computer Science (including subseries Lecture Notes in Artificial Intelligence and Lecture Notes in Bioinformatics), 2015, vol. 9232, doi: 
Jurnal Ilmiah Ilmu Komputer Vol. 7, No. 2, September 2021

(P) ISSN 2442-451X

Fakultas Ilmu Komputer

(O) ISSN 2503-3832

Universitas AL Asyariah Mandar

10.1007/978-3-319-23404-5_1. 